\title{
PROMOTING GREEN ENVIRONMENT BY PREDICTING GREEN PUBLIC TRANSPORTATION USAGE
}

\author{
PUVANESVARAN AYER SAMY ${ }^{1}$, SARINA ISMAIL ${ }^{* 1}$ AND THURASAMY RAMAYAH ${ }^{2}$ \\ ${ }^{1}$ Faculty of Business and Social Environment, Universiti Malaysia Terengganu, 21030 Kuala Nerus, Terengganu, Malaysia. \\ ${ }^{2}$ School of Management, Universiti Sains Malaysia, 11800, Pulau Pinang, Malaysia.
}

*Corresponding author: maratree.p@msu.ac.th

Submitted final draft: 23 June $2020 \quad$ Accepted: 4 August 2020

http://doi.org/10.46754/jssm.2021.06.015

\begin{abstract}
This study utilises the Theory of Reasoned Action (TRA) to examine the relationship between intention to use green public transportation, attitude, subjective norm, price and service quality. Quantitative research using an intercept survey approach was employed, involving a total of 193 respondents in this study. Analysis of Partial Least Square (PLS) was used to examine the suggested relationship. The result, however, indicates that there is no relationship between attitude and intention. Meanwhile, subjective norms, price, and service quality were significant predictors of green public transportation usage intention. This study contributes not only to green consumer behaviour but also to the management insights regarding green transportation and environment.
\end{abstract}

Keywords: Green public transportation usage intention, attitude, subjective norm, price, service quality.

\section{Introduction}

In the last decade, environmental issues such as global warming, air and water pollution have been significant issues affecting the quality of life that has led to increased awareness of the environment. (Akehurst et al., 2012; Han \& Kim, 2010; Min, Hong et al., 2012). The global $\mathrm{CO}_{2}$ emission rose to $37.1 \mathrm{bn}$ tonnes in 2018 , and one of the main contributors came from transportation (The Guardian, 2018; The NST, 2017). Moreover, transportation is an essential requirement for an individual; hence, the demand for transport services have increased in this modern era (Balachandran \& Hamzah, 2017; Mehdizadeh et al. 2019). In Malaysia, the main contributors to pollution are public and private transportation, which account for $17 \%$ of the overall CO2 emission (The NST, 2017). On the issue of climate change, the transportation sector often ignores the import of sustainability (Balachandran \& Hamzah, 2017; Sharaf et al. 2015). Therefore, we need to minimise the environmental problem and increase sustainable and green consumption patterns to allow changes in consumer behaviour and cultural practices (Khan et al. 2015). In Malaysia, studies relating to public transportation mainly focused on safety and customer satisfaction (Tan et al. 2019;
Wang et al. 2016), quality (Ahmad et al. 2014), acceptance (Rezai et al. 2013) environment consent (Borhan et al., 2014), electronic vehicle adoption (Hardman et al. 2016) and eco-friendly fuel vehicles (Halder et al. 2016; Todorovic \& Simic, 2019), sustainable transportation (Anfinsen et al. 2019; Sultana et al. 2017; Wu et al. 2019) energy consumption (Tseng \& Hung, 2013; Varela-Candamio et al. 2018; Zhili et al. 2019), air pollution and emissions from greenhouse gases (López et al. 2019; Rupp et al. 2019; Zahedi et al. 2019). Meanwhile, studies on green consumer behaviour is linked to green buying (Sharaf et al. 2015; Sharma et al. 2019; Vazifehdoust et al. 2013), green consumption (Paul et al. 2016; Ritter et al. 2015; Sun et al. 2019; Vita et al., 2018; Zhao et al. 2014) green advertisement (Fuiyeng \& Yazdanifard, 2015; Kanchanapibul, Lacka, Wang, \& Chan, 2014; Kumar, 2017; Vazifehdoust et al., 2013, and green practices (Choshaly, 2018; DiPietro et al. 2013; Rezai et al. 2013b; Yadav et al. 2017).

Based on present understanding, there seems to be a lack of study on green public transportation. As we can see green consumer behaviour can be defined as consumer attitudes, perception or believes that they are using green products or service, and they are more 
dependant on environmentally friendly products which are free from pollution (Khan et al., 2015). Green consumers will contribute and expose green behaviour to society. They will play three essential roles as a green consumer such as buyer, payer, and user. As a customer, they choose and purchase green products or services and are ready to pay a fair price for said products or services if they are of high quality and have little or no adverse environmental impact (Chekima et al., 2015). Therefore, it is essential to understand more about the factors that influence customer use of green public transportation, especially in Malaysia which can contribute to environmental-friendly behaviour and the sustainability of the city (Mehdizadeh et al., 2019).

\section{Research Model and Hypotheses}

\section{Green Public Transportation Usage Intention and Theories}

Theory of reasoned action (TRA) is among the most fundamental and influential theories applied in explaining behaviours that focus on their attitudes and beliefs (Halder et al., 2016). Because of their effectiveness in explaining different human behaviours, these sociopsychological theories were widely used and applied in a variety of contexts (Ajzen, 1991; Ajzen \& Fishbein, 2005). This model is used to consider the behaviour, intention driven by attitude and subjective norms of green producr users (Venkatesh at el., 2003). Studies of customer intent on consumer behaviour are well-known and play an essential part in the decision-making process, and many research papers have identified the best determinants to customer usage intention (Chekima et al., 2015). Customer usage intention is defined by Ajzen and Fishbein (2005) as a customers readiness and willingness to utilise product or services. Studies have also identified green usage intentions as an individual's willingness to consider and prefer to use green products and services rather than conventional products and services upon applying the decision-making process (Aman at el., 2012).
Customers who are concerned about the environment will often be willing to use green public transport (Tan et al., 2019; Wang et al., 2016). The intention of the customer is the individual's eagerness and willingness to perform the behaviour (Ismail, 2012). The previous studies have found that the higher its intention to engage in a specific behaviour, the more likely its real performance would be (Alversia et al., 2015; Jafarzadeh, 2012; Menozzi et al., 2015). A consumer's intention to go green depends on his perception of green movements and campaigns, as well as the benefits of green living (Rezai et al., 2013a). The intention to use relates to the intention of the individual to buy a specific brand, which they select after making an individual evaluation (Sharaf et al., 2015). Therefore a customers intentions are crucial when predicting green purchases (Choi et al. 2019).

\section{Attitude}

Attitude is the primary factor in influencing a consumers' usage intention (Choi et al. 2019). It can be determined by the behaviour that a customer shows when they plan to acquire a product or service to satisfy their requirements. Attitude relates to the negative or positive assessment of a specific behaviour by an individual. (Halder et al., 2016; Hong et al. 2016; Safa \& Von Solms, 2016; Wang et al., 2016). Moreover, attitude also described as the consequence of a consumer's evaluation of specific behaviours (Ajzen, 1991). Attitudes are also defined as persistent favourable or unfavourable feelings about individuals, objects or problems (Mohd Noor et al., 2012). Additionally, an attitude is defined as a psychological feeling of consumers' through evaluations (Aman et al., 2012). Research has also found that environmental concerns of customers are directly related to their attitudes. (Kai et al., 2016; Paul et al., 2016; Yadav et al., 2016), and that behaviour is the most reliable predictors of the intention to buy green products (Maichum et al., 2016; Paul et al., 2016; Yadav et al., 2016). 
Meanwhile, consumers attitude on environmental awareness, environmental ethics, and beliefs have the most substantial positive impact on their intention to use green products (Lai et al., 2016). Furthermore, attitude is an individual behavioural experience that assesses whether one's behaviour towards green usage is advantageous or disadvantageous (Chen et al., 2016). Therefore, it can be postulated that the attitude of passengers positively influences their intention to use green public transport.

H1 A positive attitude will influence consumer green public transportation usage intention positively.

\section{Subjective Norm}

Subjective norm represents the impact of other people views (family, friends, peers) on individual behaviour (Gottschalk et al., 2013) and a level of social pressure that an individual feels to participate in or abstain from certain behaviours. (Aertsens et al., 2009; Nguyen et al., 2018). Past research found that subjective norms are perceived views or perceptions of others that can affect individual decision making (Maichum et al., 2016)information on the consumers' purchase intention towards green products in developing countries, such as Thailand, is lacking. This study aims to investigate Thai consumers who are aged over 18 years, and whose base education is high school, on purchase intention for green products by using an extended framework of the theory of planned behavior (TPB. Furthermore, the individual not only decides for themselves but also on behalf of others or under the influence of others (Ham et al., 2015). Previous research papers have discovered that a subjective norm is a powerful predictor that is linked positively to behavioural intentions (Choshaly, 2018; Leong, 2015; Mohammed Alqasa et al., 2014; Ogutu et al., 2014).

Consumers who are concerned about environmental issues and whose others values, beliefs and norms are positively aligned with environmental causes are more likely to engage in green behaviours (Goh et al., 2015; Joshi et al., 2015; Khan et al., 2015). It can also be discovered that individual environmental concerns also influence the behaviour of others through peer group or family pressure, acting as vital others who adopt or reject green buying behaviour. (Paul et al., 2016) a critical variable in green marketing literature, intending to achieve triple bottom line (TBL. The impact of the subjective norm, such as environmental groups, green community and green movements, is also an essential factor in determining the intention of the passenger to go green (Golnaz et al., 2013). Therefore, it proposes the usage of green public transportation intention is positively related to the subjective norm.

H2 Subjective norms will influence consumer green public transportation usage intentions positively.

\section{Price}

Price is essential in determining the intention of using green public transportation. With the high expenses of fuel cell and battery systems being major obstacles for hybrid buses (Hardman et al., 2016; Rupp et al., 2019) the replacement of internal combustion engine vehicles (ICEVs. A few studies found that higher prices have an adverse effect on the selection of green products by consumers (Gan et al., 2008; Huang et al., 2004).

Furthermore, when many consumers start using green public transportation, it will help to reduce the operating costs and help reduce the effects of global warming (Halder et al., 2016; King et al., 2019; Lin et al., 2015). The price sensitivity has a strong relationship on the buying intentions of consumers that want to go green (Hsu et al., 2017). Thus consumers will make a choice based on location and price when selecting the best transportation mode (Biswas et al., 2016; Padel et al., 2015). Available literature shows that researchers have recognised that prices could reduce the most critical transport problems, such as traffic, accidents, air pollution and noise (Doğan et al., 2018). 
On top of that, the pricing strategy plays an important element towards the efficient and sustainable transport system (Han, et al., 2019). Pricing strategy not only affects the customer but also the government agencies due to the highly maintained and operating cost for public transportation services (Shivakumar, 2018). Therefore, the price has a negative effect on passengers' intention to use green public transportation.

H3 Higher prices will influence consumer's willingness to green public transportation negatively.

\section{Service Quality}

The service quality has the most substantial potential to increase a passengers attitude to use public transportation and also attract new bus passengers. Service quality, including passenger safety, bus schedule, and customer service, will directly affect the usage intention (Gordon et al., 2000; Murti et al., 2013). Providing excellent service quality of public transportation will indirectly increase a passengers attitude toward the usage intention, while poor quality of service will increase the negative attitude towards the usage of public transport. Thus, the quality of service can influence the public's willingness to use public transportation through attitude (Standing et al., 2019).
The service attributes such as passenger safety, reliable driver, bus cleanliness can contribute to higher factor of service quality (Chaudhry et al., 2018). Basically, in order to increase public transportation usage, public transportation companies should accommodate excellent service quality in order to attract more passenger (Belz et al., 2016). The public transport company must provide reliable services consistently to increase better service quality (Mantovani, 2012). Ultimately by providing better service quality in the public transportation system, it can hope to attract more passengers and also solve urban pollution and traffic problems in most of the cities (Cai et al., 2019). Therefore, services quality will have a positive influence on passenger green public transportation usage intention.

H4 Service quality will influence consumer green public transportation usage intention positively.

\section{Research Model}

Figure 1 demonstrates the framework for this study by utilising the Theory of Reasoned Action (TRA) to identify the relationship between attitude, subjective norm, price, service quality, and intention, to explain on green public transportation usage intention.

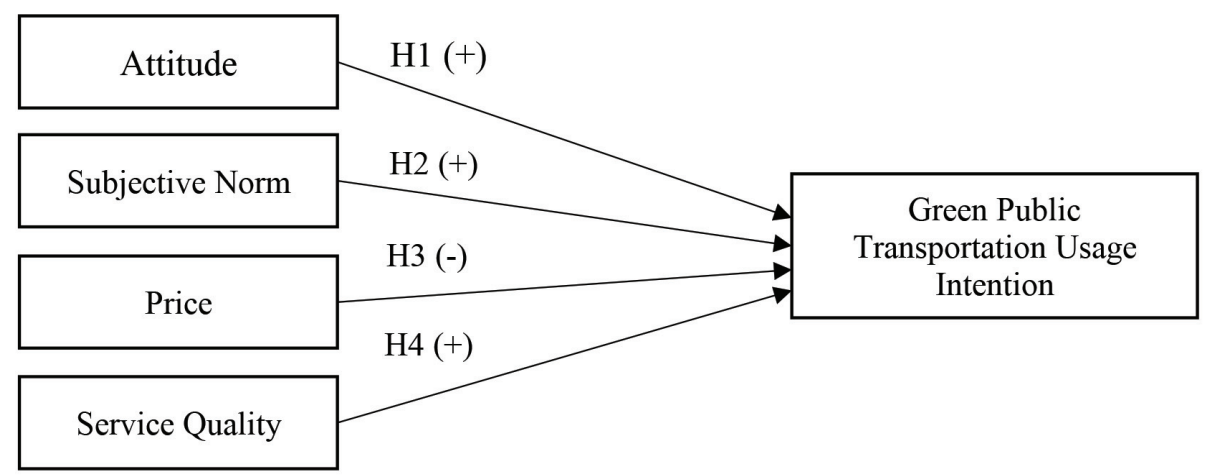




\section{Research Methodology}

This research used $\mathrm{G}^{*}$ Power software to determine the optimum sample size; the effect size was set at 0.15 (medium), the strength at 0.80 and the sample size was 85 (Faul et al., 2007). In order to overcome the non-response bias, the study increases the sample size to 400 respondents (Sekaran, 2003). Using the intercept method, 354 responses were collected from the passengers of public transportation in Melaka using structure questions. Some 208 questionnaires were excluded due to the incomplete information, and only 192 were counted as useable, which worked out to a $48 \%$ valid response rate. Sekaran (2003) suggested that a total of $30 \%$ are enough, and it also supported by $\mathrm{G}^{*}$ Power analysis indicate that
85 respondents for four predictors is enough to represent a proper sample size (Fual et al., 2007). Hence, the total of 192 respondent is enough as the minimum requirement for social science, which is above 0.80 (Hair et al., 2019).

In order to access Common Method Variance, this study utilises Harman's single factor statistical procedure to test Common Method Variance in the questionnaire. The factor analysis shows 59.43 percent of the variance, which is explained by the first factor that 15.37 percent is much smaller than the majority, so the method bias is not a serious problem with this study.

Table 1 indicates the respondent profile, which the majority of the respondent were

Table 1: Profile of respondent

\begin{tabular}{lcc}
\hline \multicolumn{1}{c}{ Item } & Frequency & Percentage \% \\
\hline Gender & 67 & \\
Male & 126 & 34.7 \\
Female & & 65.3 \\
\hline Age & 171 & \\
$20-30$ & 18 & 88.6 \\
$31-40$ & 4 & 9.3 \\
$41-50$ & & 2.1 \\
\hline Ethnic & 102 & \\
Malay & 67 & 52.8 \\
Indian & 17 & 34.7 \\
Chinese & 7 & 8.8 \\
Others & & 3.6 \\
\hline Education & 8 & \\
High School & 1 & 4.1 \\
College Graduate & 153 & 0.5 \\
Bachelor Degree & 31 & 79.3 \\
Postgraduate Degree & & 16.1 \\
\hline Occupation & 24 & \\
Government Sector & 139 & 12.4 \\
Private Sector & 8 & 72.0 \\
Self-employment & 22 & 4.1 \\
Others & & 11.4 \\
\hline Income & 11 & 5.7 \\
RM500-RM1000 & 144 & 74.6 \\
RM1001-RM2000 & 31 & 16.1 \\
RM2001-RM3000 & 7 & 3.6 \\
RM3001-RM4000 & 30 & \\
\hline Environmental Activities & 163 & \\
Yes & & \\
No & & \\
\hline
\end{tabular}


female, which is $65.3 \%$, and $34.7 \%$ are male. $88.6 \%$ respondents were between 20 and 30 years of age, followed by those between the ages of 31 and 40 years that represent $9.3 \%$ and $4 \%$ are between the ages of of 41 and 50 years.

The higher portion of the ethnic group is Malay $52.8 \%$, followed by Indian $34.7 \%$. In term of education levels, $79.3 \%$ of them have a bachelor degree, and $16.1 \%$ are postgraduate degree. $72 \%$ respondent is working in the private sector, followed by $12.4 \%$ from the government sector: the highest income, $74.6 \%$ from income group RM1001 - RM2000. Approximately $15.5 \%$ respondent take part in the environmental activity and the remaining $84.5 \%$ of which 163 respondents did not have any environment activity.

\section{Result}

This study used the Partial Least Square (PLS) analysis on the SmartPLS 3.2.8 software to evaluate the research model (Ringle et al., 2015).
The evaluation was based on two-stage analytical procedures by Anderson and Gerbing (1988), this study analysed the validity and reliability of the measurement model and checked the structural model to test the significance of path coefficients between exogenous and endogenous construct using a bootstrapping procedure (Hair et al., 2019).

\section{Measurement Model Evaluation}

In the first stage analysis, this study used the factor loadings, composite reliability (CR) and average variance extracted (AVE) to measure convergence validity of the measurement model (Hair et al., 2014). According to Hair et al. (2017) in order to archive the convergent validity, the factor loadings and composite reliability must be 0.70 or higher and average variance extracted (AVE) should be more than 0.50. As shown in Table 2, the result of the measurement model shows that all the loading are more than 0.70 , and the AVE values are more than 0.50 . Meanwhile, $\mathrm{CR}$ value is higher than 0.70 , which

Table 2: Result of the Measurement Model

\begin{tabular}{|c|c|c|c|c|}
\hline Construct & Item & Loadings & AVE & CR \\
\hline \multirow[t]{3}{*}{ Intention } & Int1 & 0.817 & 0.541 & 0.775 \\
\hline & Int3 & 0.560 & & \\
\hline & Int3 & 0.800 & & \\
\hline \multirow[t]{3}{*}{ Attitude } & A1 & 0.755 & 0.525 & 0.768 \\
\hline & $\mathrm{A} 2$ & 0.679 & & \\
\hline & $\mathrm{A} 3$ & 0.738 & & \\
\hline \multirow[t]{2}{*}{ Subjective Norm } & $\mathrm{SN} 2$ & 0.711 & 0.620 & 0.764 \\
\hline & SN5 & 0.858 & & \\
\hline \multirow[t]{5}{*}{ Price } & $\mathrm{P} 1$ & 0.876 & 0.621 & 0.890 \\
\hline & $\mathrm{P} 2$ & 0.824 & & \\
\hline & P3 & 0.851 & & \\
\hline & P4 & 0.702 & & \\
\hline & P5 & 0.664 & & \\
\hline \multirow[t]{2}{*}{ Quality } & Q4 & 0.826 & 0.604 & 0.752 \\
\hline & Q5 & 0.725 & & \\
\hline
\end{tabular}

Note: $\mathrm{AVE}=$ average variance extracted, $\mathrm{CR}=$ composite reliability. $\mathrm{SN}$ 1,3,5 and Q1,2,5 were deleted due to low loading 
indicates good reliability (Hair et al., 2019). Lastly, we identified that there was no problem with multicollinearity as all of the VIF value were less than 5 (Hair et al., 2019). Therefore this result indicated that the instrument is valid and reliable.

In the second stage, this study evaluated the discriminant validity following (Henseler et al., 2014) Heterotrait-Monotrait (HTMT) discriminant validity test. In order to archived discriminant validity, this study follows the HTMT limit at 0.85 and 0.90 suggested by a previous study (Kline, 2011).

The result of HTMT in Table 3 indicates an acceptable discriminant validity. Therefore, the measurement model in this study suggests sufficient convergent validity and discriminant validity.

\section{Structural Model Evaluation}

In the second stage, by running a bootstrapping procedure with a resample of 5000, we tested the hypotheses to evaluate the structural model, Hair et al. (2017) suggested looking at $\mathrm{R}^{2}$, beta and the corresponding t-values. The results of hypotheses presented in Table 4 indicated that the $\mathrm{R}^{2}$ for green usage intention is 0.29 , which shows that all the modelled constructs explained $29 \%$ of the variance in green usage intention, which indicates a moderate model (Cohen, 1988).

The result of hypothesis in Table 4 showed that three out of four hypotheses are supported. The H1 path concerning the relation between attitude and intention show the coefficient of $\beta=0.043, \mathrm{LL}=-0.070, \mathrm{UL}=0.211$ and not significant.

Next, the second hypothesis (H2), which dealt with the relationship between subjective norm and intention indicate coefficient of $\beta=$ $0.290, \mathrm{LL}=0.134, \mathrm{UL}=0.412$, and significant at $p<0.01$ and follow by $\mathrm{H} 3$ the relationship between price and intention indicate coefficient of $\beta=-0.296, \mathrm{LL}=-0.433, \mathrm{UL}=-0.159$, and significant at $\mathrm{p}<0.01$.The last hypothesis concerning the relationship between quality and intention indicated a coefficient of $\beta=0.175$, $\mathrm{LL}=0.041, \mathrm{UL}=0.291$, and significant at $p<0.01$.

Based on the predictors examined, this study found that price had a stronger effect on the green usage intention, and the following strong effect is quality. Lastly, three of the effect

Table 3: The result of Heterotrait-Monotrait (HTMT) Test

\begin{tabular}{lccccc}
\hline & Attitude & Usage & Price & Quality & $\begin{array}{c}\text { Subjective } \\
\text { Norm }\end{array}$ \\
\hline Attitude & & & & & \\
Intention & 0.496 & & & & \\
Price & 0.360 & 0.492 & & & \\
Quality & 0.618 & 0.540 & 0.388 & & \\
Subjective Norm & 0.804 & 0.722 & 0.303 & 0.330 & \\
\hline
\end{tabular}

Table 4: Result of Hypothesis

\begin{tabular}{clccccccccc}
\hline Hypothesis & Relationship & Beta & SE & T Values & $\begin{array}{c}\text { P } \\
\text { Values }\end{array}$ & LL & UL & Supported & $\mathbf{R}^{2}$ & $\mathbf{f}^{2}$ \\
H1 & Att $\rightarrow$ Int & 0.043 & 0.074 & 0.579 & 0.563 & -0.070 & 0.211 & No & 0.288 & 0.002 \\
H2 & SN $\rightarrow$ Int & 0.290 & 0.072 & 4.029 & 0.000 & 0.134 & 0.412 & Yes & 0.039 \\
H3 & Price $\rightarrow$ Int & -0.296 & 0.069 & 4.320 & 0.000 & -0.433 & -0.159 & Yes & 0.111 \\
H4 & Quality $\rightarrow$ & 0.175 & 0.064 & 2.751 & 0.006 & 0.041 & 0.291 & Yes & 0.101 \\
\hline
\end{tabular}




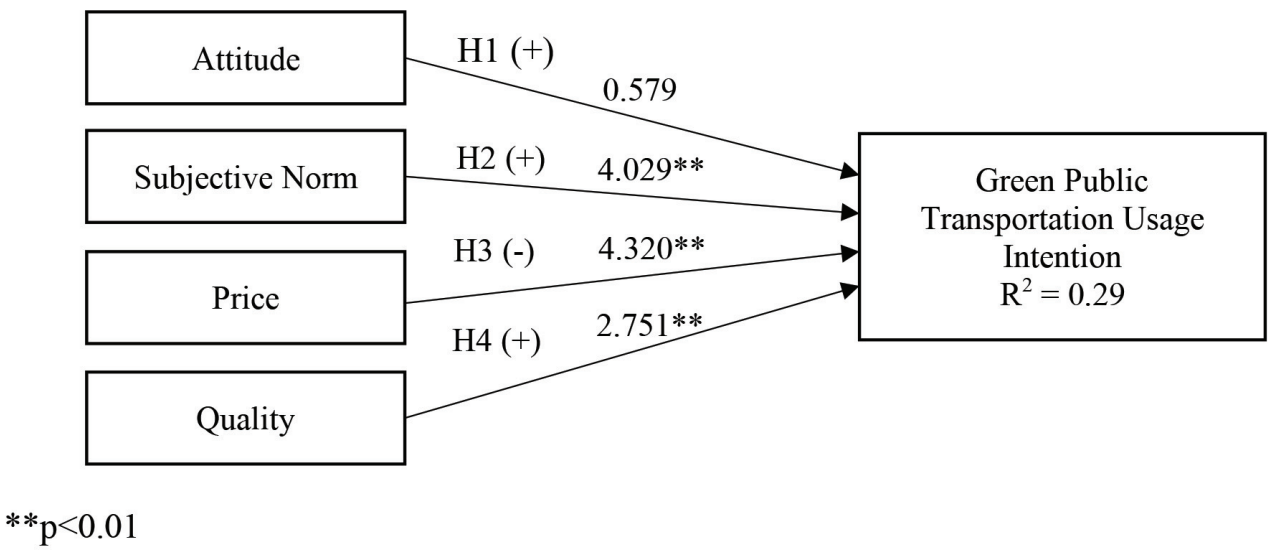

Figure 2: Hypotheses Testing

sizes $\left(\mathrm{f}^{2}\right)$ for this study achieved a small effect size of 0.02 and moderated 0.15 (Cohen, 1988). Furthermore, we also evaluated the predictive relevance of the model using the blindfolding procedure, and the $\mathrm{Q}^{2}$ value is 0.131 larger than 0 . Therefore, this model has predictive relevance (Hair et al., 2014).

\section{Conclusion}

The finding from this study indicated that there is a no relationship between attitude and the intention to use green public transportation, this show that passenger have a negative perception related to the environment and believe that their action will not bring benefit toward protecting the environment. As mention in the study of Mishra (2014), individual attitudes and beliefs about the environment are often inconsistent with behaviour.

According to the results of the current research there is a satisfactory connection between subjective norms and the intention to use green transportation. This finding proves that subjective norms affect passengers' desire to use green public transportation because they listen to their family, friends and public opinion before making a decision.

This research also found that the younger generation will seek the opinions of others on online platforms such as social media to get additional information and feedback on the services sought before making a decision, influences their thinking, preferences, and behaviours (Lin et al. 2015).

Prices were discovered to be negatively associated with the consumers' intentions to use green products or services, which suggests that price has an essential effect on a passenger's assessment process and on their final selection decision. The passenger is more conscious of the price that they need to pay when using green public transportation and this factor has significantly influenced passengers to make price sensitive judgments when using green services (Hsu et al., 2017). According to Chekima (2016), the price has always been the main concern in adopting green behaviour, and only a few individuals are prepared to pay more for environmental services. One of the reasons for this is lack of consciousness and accountability for the environmental factors and those who are price-sensitive consider the cost of green public transport as expensive.

Murti et al. (2013) found that there are two dimensions of service quality, the first being the outcome expectations of the services, and the second being the process expected from the services such as customer and employees relationship (Gordon et al., 2000). For this reason, services quality are found to be relevant to green public transportation usage intention. In context with this study, bus passengers believe they are satisfied with the services provided by 
green public transportation such as excellent customer service, travel schedules, waiting time and cleanliness. Green public transport service providers can therefore use these service quality markers to increase bus passenger numbers, which in turn should lower operating costs and prices concurrently (Tirachini et al., 2019).

\section{Implications}

The current research provides both a theoretical and a practical contribution in explaining the determinants of green public transportation behaviour, and the finding involves necessary implications that are helpful to customers, academics and also the public transportation industry. In terms of theoretical implication, this study adds support to previous research, which show that the passengers have a negative attitude toward using green transportation, and show that passengers lack of environmental awareness on the importance of reducing air pollution and global warming.

In practical terms, these findings provide essential insights to the public transportation industry to promote environmental awareness among passengers of public transportation as part as their social responsibility, Kim et al. (2005) the present study identifies key antecedents of green purchase behavior and develops a model for explaining their influence on ecological consumption. Using structural equation modeling, the effects of collectivism, environmental concern and Perceived Consumer Effectiveness (PCE proposed that customers with severe environmental concerns may be interested in green behaviour. It can also help policymakers to develop a sustainable marketing strategy for a specific group by understanding attitude and intention to use it. Meanwhile, subjective norm, price and service quality have an essential effect on the intention to use green transportation as well as providing data to the transportation industry in order to create a long-term green marketing plan for efficient promotion to encourage green travel and also enhance the public transportation system.

\section{Limitation and Suggestions for Future study}

There should be several constraints of this study, which calls for future studies. Firstly, this study only focuses on the passenger who live in Melaka; future study is suggested to explore other distinct geographic to get different opinions. Secondly, future research can use an online survey to achieve a more substantial amount of participants. This study is limited to four variables, future study is suggested to extend the model, looking into attitude and behaviour gap and how another variables such as green advertising able to influence the relationship.

\section{Acknowledgements}

This manuscript has been presented in I-OCEANS 2019 UMT on the 7 August 2019, paper ID 118-105, under the title of Promoting Green Environment By Predicting Green Public Transportation Usage.

\section{References}

Aertsens, J., Verbeke, W., Mondelaers, K., \& Huylenbroeck, G. Van. (2009). Personal determinants of organic food consumption: A review. British Food Journal, 111(10), 1140-1167. https://doi. org/10.1108/00070700910992961

Ajzen, I. (1991). The theory of planned behavior. Organisation Behaviour and Human Decision Process, 50, 179-211. https://doi. org/10.1922/CDH_2120VandenBroucke08

Ajzen, I., \& Fishbein, M. (2005). The influence of attitudes on behavior. Handbook of Attitudes and Attitude Change: Basic Principles, 173-221. https://doi.org/10.108 0/00224545.1956.9921907

Akehurst, G., Afonso, C., \& Gonçalves, H. M. (2012). Re-examining green purchase behaviour and the green consumer profile: New evidences. Journal of Consumer Marketing Marketing Intelligence \&amp; Planning Iss Journal of Consumer 
Marketing, 18(4), 503-520. https://doi. org/10.1108/00251741211227726

Alversia, Y., Michaelidou, N., \& Moraes, C. (2015). Online consumer engagement behaviour: The consumer-based antecedents. Looking Forward, Looking Back: Drawing on the Past to Shape the Future of Marketing, 849-852.

Aman, A. H. L., Harun, A., Hussein, Z., \& Author, C. (2012). The influence of environmental knowledge and concern on green purchase intention the role of attitude as a mediating variable. British Journal of Arts and Social Sciences, 7(II), 2046-9578. https://doi. org/10.1108/07363769910297506

Anderson, J. C., \& Gerbing, D. W. (1988). Structural equation modeling in practice: A review and recommended two-step approach. Psychological Bulletin, 103(3), 411-423. https://doi.org/10.1037/00332909.103.3.411

Anfinsen, M., Lagesen, V. A., \& Ryghaug, M. (2019). Green and gendered? Cultural perspectives on the road towards electric vehicles in Norway. Transportation Research Part D: Transport and Environment, 71(June 2018), 37-46. https:// doi.org/10.1016/j.trd.2018.12.003

Balachandran, I., \& Hamzah, I. B. (2017). The influence of customer satisfaction on ridesharing services in Malaysia. International Journal of Accounting \& Business Management, 5(2), 184-196. https://doi. org/10.1098/rstb.2013.0388

Belz, A., Healey, E., \& Hudgins, K. (2016). 2016 Car sharing: A feasibility study in Hong Kong. Wpi, 44-CXP-C16. https:// web.wpi.edu/Pubs/E-project/Available/Eproject-030716-041007/unrestricted/Car_ Sharing-_A_Feasibility_Study_in_Hong_ Kong.pdf

Biswas, A., \& Roy, M. (2016). A Study of consumers' willingness to pay for green products. Journal of Advanced Management Science, 4(3), 211-215. https://doi. org/10.12720/joams.4.3.211-215
Borhan, M. N., Syamsunur, D., Mohd Akhir, N., Mat Yazid, M. R., Ismail, A., \& Rahmat, R. A. (2014). Predicting the use of public transportation: A case study from Putrajaya, Malaysia. Scientific World Journal, 2014. https://doi.org/10.1155/2014/784145

Cai, H., Wang, X., Adriaens, P., \& Xu, M. (2019). Environmental benefits of taxi ride sharing in Beijing. Energy, 174, 503-508. https:// doi.org/10.1016/j.energy.2019.02.166

Chaudhry, B., Yasar, A. U. H., El-Amine, S., \& Shakshuki, E. (2018). Passenger safety in ride-sharing services. Procedia Computer Science, 130, 1044-1050. https://doi. org/10.1016/j.procs.2018.04.146

Chekima, B. C., Syed Khalid Wafa, S. A. W., Igau, O. A., Chekima, S., \& Sondoh, S. L. (2016). Examining green consumerism motivational drivers: Does premium price and demographics matter to green purchasing? Journal of Cleaner Production, 112, 3436-3450. https://doi.org/10.1016/j. jclepro.2015.09.102

Chekima, B., Khalid Wafa, S. A. W. S., Igau, O. A., \& Chekima, S. (2015). Determinant factors of consumers??? Green purchase intention: The moderating role of environmental advertising. Asian Social Science, 11(10), 318-329. https://doi. org/10.5539/ass.v11n10p318

Chen, S. C., \& Hung, C. W. (2016). Elucidating the factors influencing the acceptance of green products: An extension of theory of planned behavior. Technological Forecasting and Social Change, 112, 155-163. https://doi. org/10.1016/j.techfore.2016.08.022

Choi, D., \& Johnson, K. K. P. (2019). Influences of environmental and hedonic motivations on intention to purchase green products: An extension of the theory of planned behavior. Sustainable Production and Consumption, 18, 145-155. https://doi.org/10.1016/j. spc.2019.02.001

Choshaly, S. H. (2016). Antecedents of Malaysian consumer's green practices. 
The Open Access Journal of Resistive Economics, 11(74), 2345-4954.

Cohen, J. (1988). Statistical power analysis for the behavioral sciences. Statistical Power Analysis for the Behavioral Sciences. https://doi.org/10.1234/12345678

DiPietro, R. B., Cao, Y., \& Partlow, C. (2013). Green practices in upscale foodservice operations Customer perceptions and purchase intentions. International Journal of Contemporary Hospitality Management, 25(5), 779-796. https://doi.org/10.1108/ IJCHM-May-2012-0082

Doğan, I., Gültekin, A. B., \& Tanrıvermiş, H. (2018). Sustainable transportation. Lecture Notes in Civil Engineering (Vol. 6). Elsevier Inc. https://doi.org/10.1007/978-3319-63709-9 19

Faul, F., Erdfelder, E., Lang, A.-G., \& Buchner, A. (2007). G*Power: A flexible statistical power analysis program for the social, behavioral, and biomedical sciences. Behavior Research Methods, 39(2), 175191. https://doi.org/10.3758/BF03193146

Fuiyeng, W., \& Yazdanifard, R. (2015). Green marketing: A study of consumers' buying behavior in relation to green products. Global Journal of Management and Business Research: E Marketing, 15(5 Version 1), 1-8.

Gan, C., Han, Y. W., Ozanne, L., \& Koa, T.-H. (2008). Consumers 'purchasing behavior towards green products in New Zealand. Innovative Marketing, 4(1), 93-102.

Goh, Y. N., \& Wahid, N. A. (2015). A review on green purchase behaviour trend of Malaysian consumers. Asian Social Science, 11(2), 103-110. https://doi.org/10.5539/ass. v11n2p103

Golnaz, R., Kit Teng, P., Zainalabidin, M., \& Mad Nasir, S. (2013). Going green: Survey of perceptions and intentions among Malaysian consumers. International Business and Management,
6(1), 104-112. https://doi.org/10.3968/j. ibm.1923842820130601.1125

Gordon H. G. McDougall, \& Terrence Levesque. (2000). Customer satisfaction with services: Putting perceived value into the equation. Journal of Services Marketing, 14. https:// doi.org/10.1108/08876040010340937

Gottschalk, I., \& Leistner, T. (2013). Consumer reactions to the availability of organic food in discount supermarkets. International Journal of Consumer Studies, 37(2), 136-142. https://doi.org/10.1111/j.14706431.2012.01101.x

Hair, J. F. J., Sarstedt, M., Hopkins, L., \& Kuppelwieser, V. G. (2014). Partial Least Squares Structural Equation Modeling (PLS-SEM). European Business Review, 26. https://doi.org/10.1108/EBR-10-20130128

Hair, Joe F., Risher, J. J., Sarstedt, M., \& Ringle, C. M. (2019). When to use and how to report the results of PLS-SEM. European Business Review, 31(1), 2-24. https://doi. org/10.1108/ebr-11-2018-0203

Hair, Joseph F., Hult, G. T. M., Ringle, C. M., \& Sarstedt, M. (2017). A Primer on Partial Least Squares Structural Equation Modeling (PLS-SEM) (2nd ed.). Thousand Oaks,California: SAGE Publications Inc.

Hair Jr, J. F., Sarstedt, M., Hopkins, L., \& Kuppelwieser, V. G. (2014). Partial least squares structural equation modeling (PLSSEM). European Business Review, 26(2), 106-121. https://doi.org/10.1108/EBR-102013-0128

Halder, P., Pietarinen, J., Havu-Nuutinen, S., Pöllänen, S., \& Pelkonen, P. (2016). The theory of planned behavior model and students' intentions to use bioenergy: A cross-cultural perspective. Renewable Energy, 89, 627-635. https://doi. org/10.1016/j.renene.2015.12.023

Ham, M., Jeger, M., \& Ivkovic, A. F. (2015). The role of subjective norms in forming the intention to purchase green food. Economic 
Research-Ekonomska Istrazivanja, 28(1), 738-748. $\quad$ https://doi.org/10.1080/133167 7X.2015.1083875

Han, H., \& Kim, Y. (2010). An investigation of green hotel customers' decision formation: Developing an extended model of the theory of planned behavior. International Journal of Hospitality Management, 29(4), 659-668. https://doi.org/10.1016/j.ijhm.2010.01.001

Han, H., Lee, M. J., Chua, B. L., \& Kim, W. (2019). Triggers of traveler willingness to use and recommend eco-friendly airplanes. Journal of Hospitality and Tourism Management, 38(January), 91-101. https:// doi.org/10.1016/j.jhtm.2019.01.001

Hardman, S., Shiu, E., \& Steinberger-Wilckens, R. (2016). Comparing high-end and lowend early adopters of battery electric vehicles. Transportation Research Part A: Policy and Practice, 88, 40-57. https://doi. org/10.1016/j.tra.2016.03.010

Haroon, M., Fakar Zaman, H. M., \& Rehman, W. (2012). The relationship between Islamic. International Journal of Contemporary Business Studies, 3, 1-73.

Henseler, J., Dijkstra, T. K., Sarstedt, M., Ringle, C. M., Diamantopoulos, A., Straub, D. W., ... Calantone, R. J. (2014). Common beliefs and reality about Partial Least Squares: Comments on Rönkkö \& Evermann (2013), Organizational Research Methods, 17(2), in print. https:// doi.org/10.1177/1094428114526928

Hong, S. J., Lee, K. S., Seol, E. S., \& Young, S. (2016). Safety perceptions of training pilots based on training institution and experience. Journal of Air Transport Management. https://doi.org/10.1016/j. jairtraman.2016.05.010

Hsu, C. L., Chang, C. Y., \& Yansritakul, C. (2017). Exploring purchase intention of green skincare products using the theory of planned behavior: Testing the moderating effects of country of origin and price sensitivity. Journal of Retailing and Consumer Services, 34(October 2016), 145-152. https://doi.org/10.1016/j. jretconser.2016.10.006

Huang, J.-H., Lee, B. C. Y., \& Ho, S. H. (2004). Consumer attitude toward gray market goods. International Marketing Review, 21(6), 598-614. https://doi. org/10.1108/02651330410568033

Ismail, M. (2012). Factors influencing consumers' acceptance of mobile marketing services. https://doi.org/10.1007/s13398014-0173-7.2

Jafarzadeh, H. (2012). What forms the decision by businesses what to use search engine advertising, 323 .

Joshi, Y., \& Rahman, Z. (2015). Factors affecting green purchase behaviour and future research directions. International Strategic Management Review, 3. Holy Spirit University of Kaslik. https://doi. org/10.1016/j.ism.2015.04.001

Kai, C., \& Haokai, L. (2016). Factors affecting consumers' green commuting. Eurasia Journal of Mathematics, Science and Technology Education, 12(3), 527-538. https://doi.org/10.12973/iser.2016.2001a

Kanchanapibul, M., Lacka, E., Wang, X., \& Chan, H. K. (2014). An empirical investigation of green purchase behaviour among the young generation. Journal of Cleaner Production, 66, 528-536. https:// doi.org/10.1016/j.jclepro.2013.10.062

Khan, M. R. T., Chamhuri, S., \& Farah, H. S. (2015). Green food consumption in Malaysia: A review of consumers' buying motives. International Food Research Journal, 22(1), 131-138.

Kim, Y., \& Choi, S. M. (2005). Antecedents of green purchase behaviour: An examination of collectivism, environmental concern, and PCEE. Advances in Consumer Research, 32(1), 592-599. https://doi. org/10.1177/004057368303900411

King, N., Burgess, M., \& Harris, M. (2019). Electric vehicle drivers use better strategies 
to counter stereotype threat linked to protechnology than to pro-environmental identities. Transportation Research Part F: Traffic Psychology and Behaviour, 60, 440-452. https://doi.org/10.1016/j.trf. 2018.10.031

Kline, R. B. (2011). Principles and practice of structural equation modeling. Structural Equation Modeling, 156. https://doi. org/10.1038/156278a0

Kumar,P. (2017). Intents of green advertisements. Asia Pacific Journal of Marketing and Logistics, 29(1), 70-79. https://doi. org/10.1108/APJML-03-2016-0044

Lai, C. K. M., \& Cheng, E. W. L. (2016). Green purchase behavior of undergraduate students in Hong Kong. Social Science Journal, 53(1), 67-76. https://doi.org/10.1016/j. soscij.2015.11.003

Leong, T. P. (2015). Mediating effects of intention on the factors affecting organic food products consumption among Chinese generation $\mathrm{Y}$ in Malaysia. International Jurnal of Business Research and Management (IJBRM), 6(1), 1-19.

Lin, H.-Y., \& Hsu, M.-H. (2015). Using social cognitive theory to investigate green consumer behavior. Business Strategy and the Environment, 24(5), 326-343. https:// doi.org/10.1002/bse. 1820

López, C., Ruíz-Benítez, R., \& Vargas-Machuca, C. (2019). On the environmental and social sustainability of technological innovations in Urban bus transport: The EU case. Sustainability (Switzerland), 11(5), 1-22. https://doi.org/10.3390/su11051413

Maichum, K., Parichatnon, S., \& Peng, K. C. (2016). Application of the extended theory of planned behavior model to investigate purchase intention of green products among Thai consumers. Sustainability (Switzerland), 8(10), 1-20. https://doi. org/10.3390/su8101077

Mantovani, D. M. N. (2012). Distance education on the stakeholders' perspectives: Student's, instructor's and administrator's perceptions, 273. https://doi.org/1

Mehdizadeh Dastjerdi, A., Kaplan, S., de Abreu e Silva, J., Nielsen, O. A., \& Pereira, F. C. (2019). Participating in environmental loyalty program with a real-time multimodal travel app: User needs, environmental and privacy motivators. Transportation Research Part D, 67(December 2018), 223-243. https://doi.org/10.1016/j. $\operatorname{trd} .2018 .11 .013$

Menozzi, D., Halawany-Darson, R., Mora, C., \& Giraud, G. (2015). Motives towards traceable food choice: A comparison between French and Italian consumers. Food Control, 49, 40-48. https://doi. org/10.1016/j.foodcont.2013.09.006

Min, M., Hong, L., Ai, J., \& Wah, P. (2012). Conceptual paper: Factors affecting the demand of smartphone among young adult . Factors Affecting the Demand of Smartphone among Youth Adult, 2(2), 4449.

Mohammed Alqasa, K., Mohd Isa, F., Othman, S. N., \& Saleh Zolait, A. H. (2014). The impact of students' attitude and subjective norm on the behavioural intention to use services of banking system. International Journal of Business Information Systems, 15(1), 105. https://doi.org/10.1504/ IJBIS.2014.057967

Mohd Noor, N. A., Muhammad, A., Kassim, A., Muhammad Jamil, C. Z., Mat, N., Mat, N., \& Salleh, H. S. (2012). Creating green consumers: How environmental knowledge and environmental attitude lead to green purchase behaviour? International Journal of Arts \& Sciences, 5(1), 55-71.

Murti, A., Deshpande, A., \& Srivastava, N. (2013). Service quality, customer (patient) satisfaction and behavioural intention in health care services: Exploring the Indian perspective. Journal of Health Management, 15(1), 29-44. https://doi. org/10.1177/0972063413486035 
Nguyen, T. N., Lobo, A., \& Nguyen, B. K. (2018). Young consumers' green purchase behaviour in an emerging market. Journal of Strategic Marketing, 26(7), 583-600. https://doi.org/10.1080/096525 4X.2017.1318946

Noor Hazlina Ahmad, Ramayah, T., Imran Mahmud, Mohammad Musa, \& Anika, J. J. (2014). Modelling student entrepreneurship intention in Bangladesh using structural equation modelling.

Ogutu, R., Ogutu, M., \& Njanja, L. (2014). The moderating effect of subjective norms, perceived behavioural control and gender on the relationship between attitude towards internet advertising and purchase intention of university student in Kenya. European Journal of Business Management, 2(1), 1-37. http://ejobm.org/images/Journals/ Volume 2/The Moderating Effect Of Subjective Norms Perceived Behavioural Control And Gender On The Relationship Between Attitude Towards Internet Advertising And Purchase Intention Of University Students In Kenya.pdf

Padel, S., \& Foster, C. (2015). Exploring the gap between attitudes and behaviour Understanding why consumers buy or do not buy organic food. British Food Journal Food Journal British Food Journal Journal of Communication Management, 107(4), 606-625. https://doi. org/10.1108/00070700510611002

Paul, J., Modi, A., \& Patel, J. (2016). Predicting green product consumption using theory of planned behavior and reasoned action. Journal of Retailing and Consumer Services, 29, 123-134. https://doi.org/10.1016/j. jretconser.2015.11.006

Rezai, G., Teng, P. K., Mohamed, Z., \& Shamsudin, M. N. (2013a). Consumer willingness to pay for green food in Malaysia. Journal of International Food \& Agribusiness Marketing, 25(January), 1-18. https://doi.org/10.1080/08974438.2013.79 8754
Rezai, G., Teng, P. K., Mohamed, Z., \& Shamsudin, M. N. (2013b). Is it easy to go green? Consumer perception and green concept. American Journal of Applied Sciences, 10(8), 793-800. https://doi. org/10.3844/ajassp.2013.793.800

Ringle, Christian M., Wende, Sven, \& Becker, J.-M. (2015). SmartPLS 3. http://www. smartpls.com

Ritter, Á. M., Borchardt, M., Vaccaro, G. L. R., Pereira, G. M., \& Almeida, F. (2015). Motivations for promoting the consumption of green products in an emerging country: Exploring attitudes of Brazilian consumers. Journal of Cleaner Production, 106, 507-520. https://doi.org/10.1016/j. jclepro.2014.11.066

Rupp, M., Handschuh, N., Rieke, C., \& Kuperjans, I. (2019). Contribution of country-specific electricity mix and charging time to environmental impact of battery electric vehicles: A case study of electric buses in Germany. Applied Energy, 237(January), 618-634. https://doi. org/10.1016/j.apenergy.2019.01.059

Safa, N. S., \& Von Solms, R. (2016). An information security knowledge sharing model in organizations. Computers in Human Behavior, 57, 442-451. https://doi. org/10.1016/j.chb.2015.12.037

Sekaran, U. (2003). Research methods for business - A skill building approach. Journal of Chemical Information and Modeling, 53. https://doi.org/10.1017/ CBO9781107415324.004

Sharaf, M. A., Filzah, M. I., \& Al-Qasa, K. (2015). Factors affecting young Malaysians' intention to purchase green products. Merit Research Journal, 3(3), 2933. http://www.meritresearchjournals.org/ bm/content/2015/May/Sharaf et al.pdf

Sharaf, M. A., Isa, F. M., \& Al-Qasa, K. (2015). Young consumers' intention towards future green purchasing in Malaysia. Journal of 
Management Research, 7(2), 468. https:// doi.org/10.5296/jmr.v7i2.6998

Sharma, A., \& Foropon, C. (2019). Green product attributes and green purchase behavior: A theory of planned behavior perspective with implications for circular economy. Management Decision, 57(4), 1018-1042. https://doi.org/10.1108/MD10-2018-1092

Shivakumar, K. (2018). Customer relationship management influencing customer loyalty and satisfaction - Patients' perception in multispecialty Hospitals of Karnataka, 1(January), 45-53.

Standing, C., Standing, S., \& Biermann, S. (2019). The implications of the sharing economy for transport. Transport Reviews, 39(2), 226-242. https://doi.org/10.1080/014 41647.2018.1450307

Sultana, S., Salon, D., \& Kuby, M. (2017). Transportation sustainability in the urban context: A comprehensive review. Urban Geography, 00(00), 1-30. https://doi.org/10 $.1080 / 02723638.2017 .1395635$

Sun, Y., Liu, N., \& Zhao, M. (2019). Factors and mechanisms affecting green consumption in China: A multilevel analysis. Journal of Cleaner Production, 209, 481-493. https:// doi.org/10.1016/j.jclepro.2018.10.241

Tan, C. N. L., Ojo, A. O., \& Thurasamy, R. (2019). Determinants of green product buying decision among young consumers in Malaysia. Young Consumers, YC-12-20180898. https://doi.org/10.1108/YC-12-20180898

The Guardian. (2018, December 5). "Brutal news": Global carbon emissions jump to all-time high in 2018. The Guardian. https:// www.theguardian.com/environment/2018/ dec/05/brutal-news-global-carbonemissions-jump-to-all-time-high-in-2018

The NST. (2017, December 13). Carbon dioxide emissions causing global warming. The New Straits Times. https://www.nst.com. my/opinion/columnists/2017/12/313842/ carbon-dioxide-emissions-causing-globalwarming

Tirachini, A., \& Gomez-Lobo, A. (2019). Does ride-hailing increase or decrease vehicle kilometers traveled (VKT)? A simulation approach for Santiago de Chile. International Journal of Sustainable Transportation, $0(0), 1-18$. https://doi.org/1 0.1080/15568318.2018.1539146

Todorovic, M., \& Simic, M. (2019). Feasibility study on green transportation. Energy Procedia, 160(2018), 534-541. https://doi. org/10.1016/j.egypro.2019.02.203

Tseng, S. C., \& Hung, S. W. (2013). A framework identifying the gaps between customers' expectations and their perceptions in green products. Journal of Cleaner Production, 59, 174-184. https://doi.org/10.1016/j. jclepro.2013.06.050

Varela-Candamio, L., Novo-Corti, I., \& GarcíaÁlvarez, M. T. (2018). The importance of environmental education in the determinants of green behavior: A metaanalysis approach. Journal of Cleaner Production, 170, 1565-1578. https://doi. org/10.1016/j.jclepro.2017.09.214

Vazifehdoust, H., Taleghani, M., Esmaeilpour, F., Nazari, K., \& Khadang, M. (2013). Purchasing green to become greener: Factors influence consumers' green purchasing behavior. Management Science Letters, 3, 2489-2500. https://doi.org/10.5267/j. msl.2013.08.013

Venkatesh, V., Morris, M. G., David, G. B., \& David, F. D. (2003). User acceptance of information technology: Toward a unified view. MIS Quarterly, 27(3), 425-478. https://doi.org/10.1006/mvre.1994.1019

Vita, G., Lundström, J. R., Hertwich, E. G., Quistd, J., Ivanova, D., Stadler, K., \& Wood, R. (2018). Sustainable lifestyle scenarios to curb European environmental impact: Connecting local visions to global consequences. Under Review Ecol. 
Economics., 164(March), 106322. https:// doi.org/10.1016/j.ecolecon.2019.05.002

Wang, S., Fan, J., Zhao, D., Yang, S., \& Fu, Y. (2016). Predicting consumers' intention to adopt hybrid electric vehicles: Using an extended version of the theory of planned behavior model. Transportation, 43(1), 123-143. https://doi.org/10.1007/s11116014-9567-9

Wu, J., Liao, H., Wang, J. W., \& Chen, T. (2019). The role of environmental concern in the public acceptance of autonomous electric vehicles: A survey from China. Transportation Research Part F: Traffic Psychology and Behaviour, 60, 37-46. https://doi.org/10.1016/j.trf.2018.09.029

Yadav, R., \& Pathak, G. S. (2016). Young consumers' intention towards buying green products in a developing nation: Extending the theory of planned behavior. Journal of Cleaner Production, 135, 732-739. https:// doi.org/10.1016/j.jclepro.2016.06.120

Yadav, R., \& Pathak, G. S. (2017). Determinants of consumers' green purchase behavior in a developing nation: Applying and extending the theory of planned behavior. Ecological Economics, 134, 114-122. https://doi. org/10.1016/j.ecolecon.2016.12.019

Zahedi, S., Batista-Foguet, J. M., \& van Wunnik, L. (2019). Exploring the public's willingness to reduce air pollution and greenhouse gas emissions from private road transport in Catalonia. Science of the Total Environment, 646, 850-861. https://doi. org/10.1016/j.scitotenv.2018.07.361

Zhao, H. H., Gao, Q., Wu, Y. P., Wang, Y., \& Zhu, $X$. D. (2014). What affects green consumer behavior in China? A case study from Qingdao. Journal of Cleaner Production, 63, 143-151. https://doi.org/10.1016/j. jclepro.2013.05.021

Zhili, D., Boqiang, L., \& Chunxu, G. (2019). Development path of electric vehicles in China under environmental and energy security constraints. Resources, Conservation and Recycling, 143(June 2018), 17-26. https://doi.org/10.1016/j. resconrec.2018.12.007 